\title{
Design Thinking: a problem-solving approach for first-year undergraduate students
}

\author{
C.V.Tapia-Bastidas ${ }^{1}$, Daniel Contreras Moscol ${ }^{1}$, Isabel Alcivar ${ }^{1}$, Sharon Guaman-Quintanilla ${ }^{1}$, Guido Caicedo Rossi ${ }^{1}$ \\ ${ }^{1}$ ESPOL Polytechnic University. Escuela Superior Politécnica del Litoral, Centro de Emprendimiento e Innovación i3lab, \\ Campus Gustavo Galindo Km. 30.5 Vía Perimetral, P.O. Box 09-01-5863, Guayaquil, Ecuador, \\ vtapia@espol.edu.ec, dcontrer@espol.edu.ec, mialciva@espol.edu.ec, seguaman@espol.edu.ec, caicedo@espol.edu.ec
}

\begin{abstract}
The present article describes the experience of applying Design Thinking to approach the deficiency in problem-solving skills in freshmen undergraduate students. The quantification of the methodology applied at ESPOL is performed by measuring specific student outcomes aiming problem-solving in 817 students. Additionally, the sponsors and students' feedback are used as an indirect measurement of the acceptance and effectiveness of the proposed methods.

Keywords- Design Thinking, student outcomes, soft skills, problem-solving.
\end{abstract}

Resumen- El presente artículo describe la experiencia durante la aplicación de Design Thinking como vía para mejorar la deficiencia en habilidades de resolución de problemas evidenciada en estudiantes de primer año de universidad. La medición del efecto de la implementación de esta metodología en la ESPOL se realizó considerando 817 estudiantes y su desempeño en los objetivos educaciones relacionados a la resolución de problemas. Adicionalmente, se empleó la retroalimentación por parte de sponsors y estudiantes como medidas indirectas de la aceptación y efectividad de los métodos propuestos.

Palabras clave- Design Thinking, objetivos de aprendizaje, habilidades esenciales, resolución de problemas.

\section{INTRODUCTION}

Escuela Superior Politécnica del Litoral (ESPOL) was born due to the need, at region-wide level, for institutions of higher education specialized in scientific and technical education in Ecuador. It is aimed at developing scientific research and innovation in different areas. In 2003, ESPOL created the Entrepreneurship Center and recognized entrepreneurship education as an important mean to increase entrepreneurial awareness and also as a way to help in developing soft skills that would be useful to students after graduation [1]. After a pilot of one semester with five groups from engineering degrees during 2015, ESPOL resolved in 2016 to have a mandatory course on entrepreneurship and innovation for all undergraduate students; this course can be taken by students after approval of $50 \%$ of their curricula. Over the years, the course has widened its focus from startup creation - commonly related to earlier definitions of entrepreneurship - to the more general focus of value creation. This focus is consistent with broader definitions of entrepreneurship such as the one given by professor Howard Stevenson: "entrepreneurship is the pursuit of opportunity beyond resources controlled" [2]. Also,

Digital Object Identifier (DOI):

http://dx.doi.org/10.18687/LACCEI2019.1.1.389

ISBN: 978-0-9993443-6-1 ISSN: 2414-6390 such focus is particularly important for a mandatory course because it allows a better fit with career paths that are not related to creating a business, such as social entrepreneurship or intrapreneurship. Although the course in general is considered to have a positive impact on ESPOL's students, faculty meetings have revealed that many of the project ideas students propose are related to problems that students encounter within the university. ESPOL campus is far from the city and students frequently spend all day on campus. Also, depending on the degree, not many courses at ESPOL provide students enough exposure to problems happening in the city. A possible action to help remedy this situation is to increase students' activities that engage them with stakeholders in industry and society as part of their coursework. After all, new value creation is the result of co-existence of entrepreneurial opportunities and individuals [3]. The ideas entrepreneurs develop are often inherent in the means available to them [4].

ESPOL carried out a curriculum reform and one of the strategies discussed was to have a problem-solving course for all students at ESPOL. The Entrepreneurship Center was involved in the team analyzing the proposal and eventually suggested to design the new problem-solving course as a nontraditional course, in which the focus wasn't on analytical tools, such as courses traditionally taught in engineering programs at American universities. Instead, the core proposal was to have this problem-solving course be based on the Design Thinking methodology, to be taken by all freshmen undergrad students at ESPOL. The course would have a focus on analyzing and developing solution proposals and prototypes for Nongovernmental organizations (NGOs) in the city and, if possible, for for-profit organizations willing to participate in the program as well. Consequently, the students would benefit by working at the very early stage of their professional education in some of the soft competencies that are important for professional life such as: collaboration and teamwork, creativity, problem solving, and empathy [5].

The problem-solving course "Análisis y Resolución de Problemas" (ARP1) started as a pilot project in the second academic semester of 2015, with one class section of around 30 students. After that, the project escalated and in the second academic semester of 2016, the ARP1 course had 10 formal class sections. From the first semester of 2017 onwards, the ARP1 course has been part of every undergraduate program at ESPOL, having around 30 multidisciplinary class sections each academic semester, and exposing freshmen students to the

$17^{\text {th }}$ LACCEI International Multi-Conference for Engineering, Education, and Technology: "Industry, Innovation, And Infrastructure for Sustainable Cities and Communities", 24-26 July 2019, Jamaica. 
challenge of designing innovative solutions for real-life problems.

\section{LITERATURE REVIEW}

Design Thinking (DT) has gained popularity across business and also in Higher Education. Tim Brown, one of its most prominent advocates, defines DT as "a discipline that uses the designer's sensibility and methods to match people's needs with what is technologically feasible and what a viable business strategy can convert into customer value and market opportunity" [6]. On the other hand, Guaman-Quintanilla et. al. [5] provides an extended definition as a result of a scoping review of DT in Higher Education. They describe it as a way to solve ill-defined problems using some methods taken from designers, which can be adapted to different contexts applying a human-centered and prototype-driven approach, fostering creativity and promoting teamwork.

Universities are betting on implementing DT throughout the curriculum in order to equip students with skills and knowledge beyond their own areas in a safe learning environment [7]. For other researchers, DT is an evolution from earlier models such as the CDIO framework (Conceiving, Designing, Implementing, Operating) and PBL (Problem Based Learning) [8].

Guaman-Quintanilla et. al. [5] found that there is an urgent agenda for researchers to assess the effects of DT interventions on students' skills, in a robust way. In their work, they found various skills related to Design Thinking; most of them also connected to the so-called 21st. Century Skills. One of those skills is problem-solving. Additionally, according to the Association of American Colleges \& Universities (AAC\&U), problem-solving is the process of designing, evaluating and implementing a strategy to answer an open-ended question or to achieve a desired goal [9].

There is an extensive literature about problem-solving; researchers have tried to explain its elements, its main drivers, as well as its impact as a learning outcome. Jonassen [10] agreed with most psychologists and educators who consider problem-solving as the most important learning outcome for life. He criticizes formal education curricula which rarely requires students to solve meaningful problems. Jonassen also points out that the few problems students faced during their academic life are well-structured. However, those are not the same type of problems that they will have to deal with in real life. In consequence, this reality represents a complex problem that instructional design should reform. Gagné, another prominent researcher in problem-solving, states that "regardless of the relevance of various content areas of the curriculum, the really important, central point of education is to teach people to think, to use their rational powers, to become better problem solvers" [11]. In his work, Gagné explains three kind of capabilities for successful problem-solving: i) the concepts and rules (intellectual skills) relevant to the problem, ii) verbal knowledge as a vehicle for thought of a productive sort, and iii) cognitive strategies or also called "task strategies". He finally argues that all of them can be learnable.

Students may face difficulties when applying DT as a tool to tackle real-life problems. Santos et. al. [12] found out that students who implemented DT as a tool to tackle problems from NGO's, struggled during the collaborative learning processes due to the lack of ability to work as part of a multidisciplinary team. On the other hand, the authors remark that the students were able to reach the prototype stage and the validation of valuable solutions for the NGO's who were part of the study. The solution proposed considered users' needs through the application of empathy tools along the design process.

\section{METHODOLOGY}

\section{A. Design thinking as framework to develop problem-solving abilities}

ESPOL has adopted Design Thinking as a methodology to develop problem-solving abilities in freshmen undergraduate students throughout all its undergraduate programs. A comprehensive group of scholars at the university has been working together to apply the methodology considering the Ecuadorian reality.

ESPOL has envisioned a three-level approach to develop problem-solving abilities in students throughout their undergraduate experience: (i) freshmen, (ii) students in midundergraduate program and (iii) senior students developing their capstone project prior graduation. In this work, the authors describe an analysis made over the results obtained from freshmen students during the first academic semester of 2018, enrolled in the ARP1 course where the Design Thinking methodology is taught.

Particularly interesting is the multidisciplinary approach applied, given that freshmen students are all mixed together in the ARP1 course; hence, each course section was conformed by students from arts, humanities, science, and engineering programs. This means that ARP1 course is multidisciplinary in nature, so to include a holistic development in the students from the very beginning of their undergraduate education. Additionally, it is expected from the ARP1 course to enhance the development of soft skills in students — one of them being problem-solving skills.

\section{B. Evaluation of learning outcomes for the ARP1 freshmen course}

A measurement for the ability to solve real problems by freshmen students is analyzed in the present work, considering the work done in the ARP1 course taught at ESPOL. The ARP1 course has four learning outcomes, all of them related to developing problem-solving abilities:

- Outcome 1: Identify and understand problems using Design Thinking research and empathy tools.

- Outcome 2: Define a problem after applying Design Thinking tools systematically, in order to propose innovative solutions later in the process.

Digital Object Identifier: (to be inserted by LACCEI).

ISSN, ISBN: (to be inserted by LACCEI).

$17^{\text {th }}$ LACCEI International Multi-Conference for Engineering, Education, and Technology: "Industry, Innovation, And Infrastructure for Sustainable Cities and Communities", 24-26 July 2019, Jamaica. 
- Outcome 3: Propose innovative ideas to solve problems, using ideation, prototyping and testing tools to validate them.

- Outcome 4: Communicate effectively the solutions proposed.

Each learning outcome defines a crucial aspect of the Design Thinking methodology, from the very understanding of the problem, the translation into a defined problem, to the final high-fidelity prototyping and validation of the solutions proposed.

To assess whether problem-solving abilities were developed in students while taking the ARP1 course, the final report for the course project was used as a tool to measure the four learning outcomes stated above.

The written report is schematically divided into eight sections: Introduction, Discovery (research), Empathy, Problem Definition, Ideation, Prototyping, Testing and Validation, and Conclusions. For Outcome 1, the "Problem Definition" section was used, where students evidence how they used research, empathy and define tools from the Design Thinking methodology to understand why the problem happens in the organization under study. For Outcome 2, the "Problem Definition" section was also used, specifically, the Point of View (POV) statement for the problem analyzed. For Outcome 3, "Ideation", "Prototyping" and "Testing" sections were used; these sections compile students' work in generating ideas and evidencing how they can have an impact in solving the POV they defined previously, and the level of innovation of such ideas proposed. Finally, for Outcome 4, all sections from the written report were considered to evidence the students' ability to argue their ideas and communicate their results effectively.

A total of 21 instructors were part of the study; they were divided into four even groups, in order to measure each of the four learning outcomes described earlier. Each group of instructors developed the grading rubric for the assigned outcome, to avoid biased results in the study. The grading rubrics were socialized, analyzed, discussed and approved in consensus by all the instructors included in the study. The grading rubrics categorize the students' performance in four levels: Initial (0-2 points), Developing (3-4 points), Satisfactory (5-7 points) and Exemplary (8 points), for each outcome assessed. Table 1 summarizes the criteria evaluated on each of the grading rubrics. Each instructor assessed his/her course section, and then each group of instructors compiled the information to obtain an overall assessment of each learning outcome for the 817 students who were enrolled in the course.

\section{Evaluation of Students and Sponsors' feedback}

As part of the strategy to develop problem-solving abilities, ESPOL requires students to immerse in real-life problems. This is particularly challenging when considering freshmen students. On the one hand, it was uncertain how freshmen students would behave and perform when required to interact outside their comfort zone (i.e. deal with real-life problems outside their university environment). On the other hand, looking for sponsors (small and mid-size businesses, associations, nonprofit-organizations, etc.) willing to be part of this initiative has been a difficult task, that every instructor has taken with enthusiasm each semester.

Two surveys were designed to estimate the acceptance of ESPOL's methodology to develop problem-solving abilities in students: one for students and one the sponsors, both conducted using Microsoft Forms ${ }^{\circledR}$.

The students' survey was sent one week prior to the delivery of the final report and it was stated that their contributions will remain anonymous and will not be part of the grading scheme for the course, aiming to obtain unbiased and realistic information. The survey contained 25 questions, aiming to obtain the students feedback in three major aspects: teamwork, creativity and problem-solving abilities. The following section presents the results for the latter aspect.

TABLE I.

CRITERIA TO EVALUATE THE LEARNING OUTCOMES FOR THE ARP1 COURSE

\begin{tabular}{|c|c|}
\hline $\begin{array}{l}\text { Criteria for Learning } \\
\text { Outcome 1: Identify and } \\
\text { understand problems using } \\
\text { Design Thinking research and } \\
\text { empathy tools }\end{array}$ & $\begin{array}{l}\text { Students should evidence that they } \\
\text { have successfully identified the } \\
\text { actors that are directly or indirectly } \\
\text { related to the problem. They should } \\
\text { also show a sufficient compilation of } \\
\text { research relevant to the problem } \\
\text { under study, as well as interviews } \\
\text { and observations to actors identified. } \\
\text { Additionally, they should evidence } \\
\text { the use of empathy tools and how } \\
\text { they contribute to the overall } \\
\text { understanding of the problem. }\end{array}$ \\
\hline $\begin{array}{l}\text { Criteria for Learning } \\
\text { Outcome 2: Define a problem } \\
\text { after applying Design } \\
\text { Thinking tools systematically, } \\
\text { in order to propose innovative } \\
\text { solutions later in the process. }\end{array}$ & $\begin{array}{l}\text { Students should evidence they } \\
\text { properly used define tools to identify } \\
\text { the causes of the problem assigned } \\
\text { through a Point of View statement } \\
\text { that clearly states: who is the user, } \\
\text { what are his/her needs, and which } \\
\text { insights support such statement. }\end{array}$ \\
\hline $\begin{array}{l}\text { Criteria for Learning } \\
\text { Outcome 3: Propose } \\
\text { innovative ideas to solve } \\
\text { problems, using ideation, } \\
\text { prototyping and testing tools } \\
\text { to validate them. }\end{array}$ & $\begin{array}{l}\text { Students should evidence they built } \\
\text { and tested low-fidelity prototypes } \\
\text { with a representative sample of users. } \\
\text { They also show evolution of such } \\
\text { prototypes by building and testing at } \\
\text { least one high-fidelity prototype. } \\
\text { Also, they argue how the proposed } \\
\text { solution that was tested have an } \\
\text { impact on the defined problem. }\end{array}$ \\
\hline $\begin{array}{l}\text { Criteria for Learning } \\
\text { Outcome 4: Communicate } \\
\text { effectively the solutions } \\
\text { proposed. }\end{array}$ & $\begin{array}{l}\text { Students should evidence a clear } \\
\text { understanding and delimitation of the } \\
\text { problem, based on the research, } \\
\text { empathy and definition tools used } \\
\text { from the Design Thinking } \\
\text { methodology. They successfully } \\
\text { argue the impact of the solutions } \\
\text { proposed by building and testing } \\
\text { prototypes, and clearly present their } \\
\text { learnings and conclusions from the } \\
\text { learning experience in the course. }\end{array}$ \\
\hline
\end{tabular}

One requirement for the ARP1 course at ESPOL is that the sponsor is an active participant of the learning process. The sponsor must be committed to allot time to share insights with the students' group, be willing to provide information, let the

$17^{\text {th }}$ LACCEI International Multi-Conference for Engineering, Education, and Technology: "Industry, Innovation, And Infrastructure for Sustainable Cities and Communities", 24-26 July 2019, Jamaica. 
students visit the locations, and let the students interact with his/her employees and customers. Due to the demanding nature of this relationship with sponsors, it is important to get their feedback, regarding three major aspects: (i) their willingness to participate in such projects, (ii) the impact and satisfaction of the solutions presented, and (iii) their point of view about the interaction between freshmen students with real-life problems. The sponsors survey was sent after the delivery of the final report and contained 5 questions aiming to obtain the sponsors feedback regarding the aspects mentioned before.

The information collected from both surveys was compiled, analyzed and scrutinized by the instructors who were part of this study, and the results are presented in the following section.

\section{RESULTS}

In this section, the results obtained after applying Design Thinking as a framework to develop problem-solving abilities in freshmen students are presented. First, the analysis of the attainment of the four learning outcomes approached during the ARP1 course is depicted. Then, a summary of the feedback obtained from both students and organizations is shown. All results presented correspond to the first academic semester of 2018.

A. Problem-solving learning outcomes for the ARP1 course To measure each learning outcome, students' performance was categorized in four levels: Initial, Developing, Satisfactory, and Exemplary, based on the grading rubrics detailed in the previous section. The results depicted correspond for a total of 817 freshmen students enrolled in different undergraduate programs, who worked in groups of 5-7 students at different local organizations. These results are summarized in

Outcome 1: Identify and understand problems using design thinking research and empathy tools

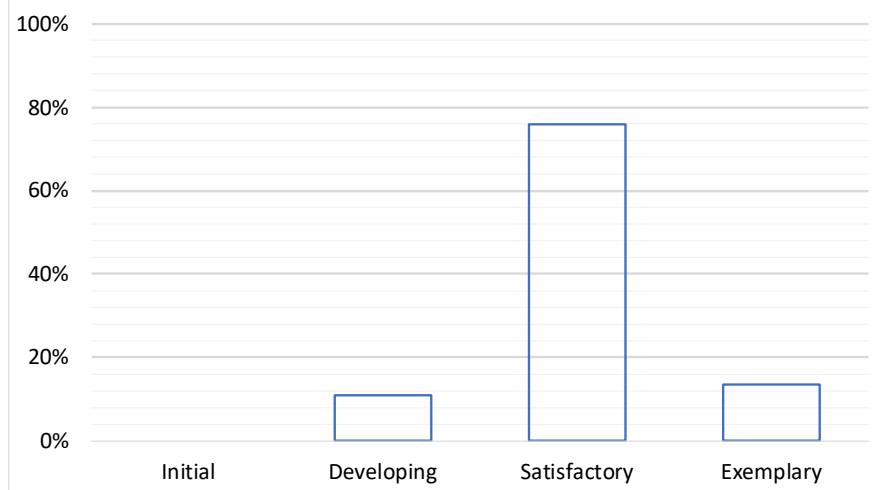

Figure 1 to 4.

For the learning outcome 1 (Figure 1), 89\% of students fall under a satisfactory level of accomplishment or higher. For the learning outcome 2 and 3 (Figures 2 and 3), 78\% of students fall under a satisfactory level of accomplishment or higher. Finally, for the learning outcome 4 (Figure 4), 95\% of students fall under a satisfactory level of accomplishment or higher. Figure 5 summarizes results for Satisfactory and Exemplary levels combined, for each learning outcome. In general, the vast majority of students fall under a satisfactory or higher level of performance for all learning outcomes of the ARP1 course.

Outcome 1: Identify and understand problems using design thinking research and empathy tools

$100 \%$

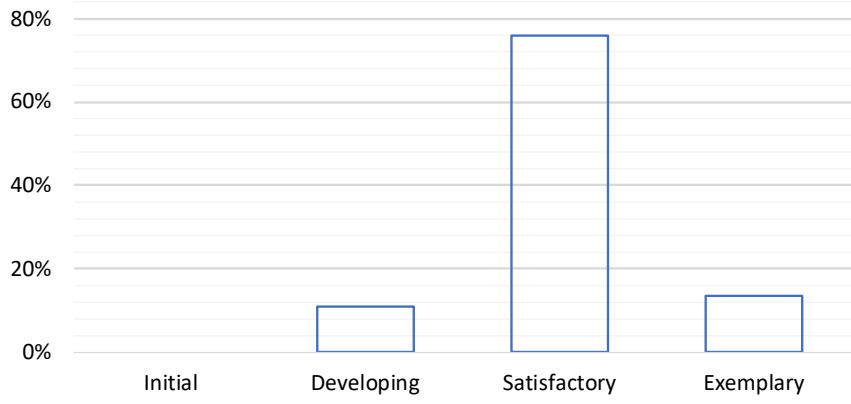

Figure 1. Outcome 1 - Learning Outcomes

Outcome 2: Define a problem after applying design thinking tools systematically, in order to propose innovative solutions later in the process

$100 \%$

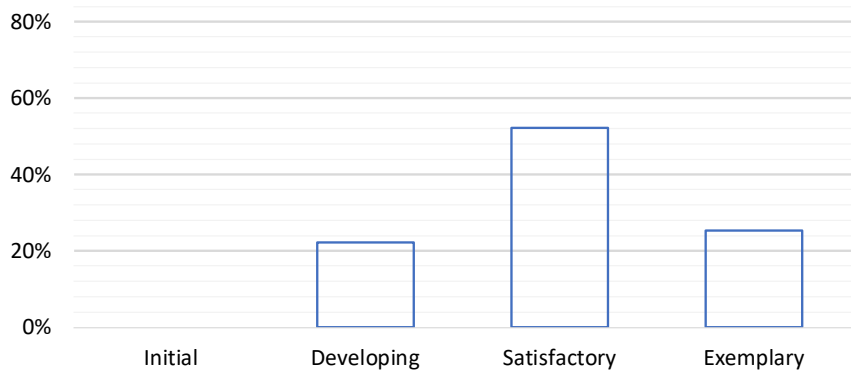

Figure 2. Outcome 2 - Learning Outcomes

Outcome 3: Propose innovative ideas to solve problems, using ideation, prototyping and testing tools to validate them

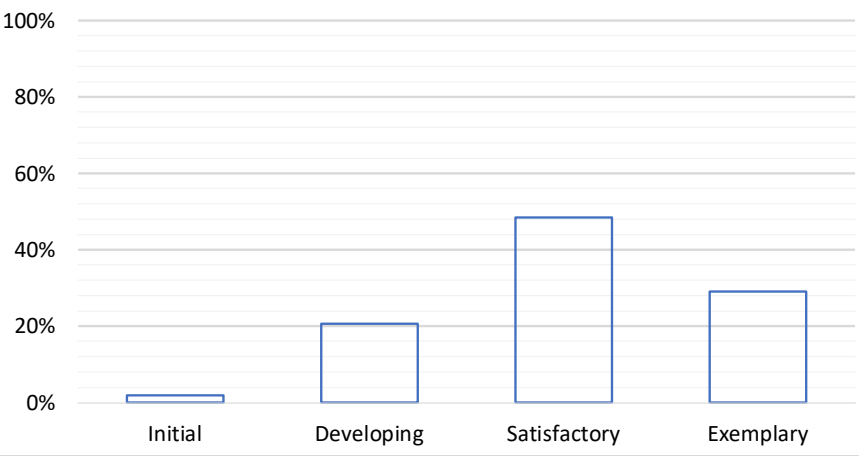

Figure 3. Outcome 3 - Learning Outcomes

$17^{\text {th }}$ LACCEI International Multi-Conference for Engineering, Education, and Technology: "Industry, Innovation, And Infrastructure for Sustainable Cities and Communities", 24-26 July 2019, Jamaica. 


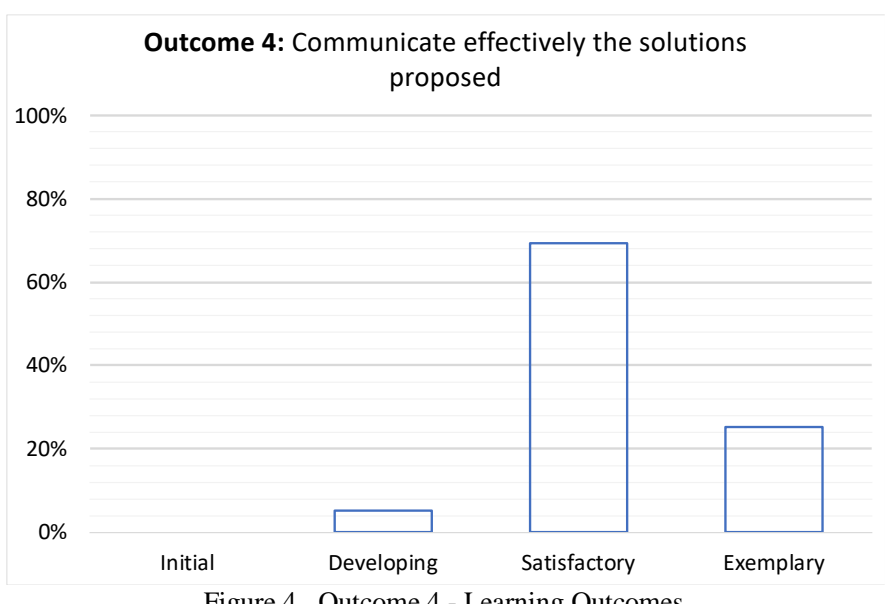

Figure 4. Outcome 4 - Learning Outcomes

Satisfactory and Exemplary levels (2018-1) corresponding to each learning outcome analyzed

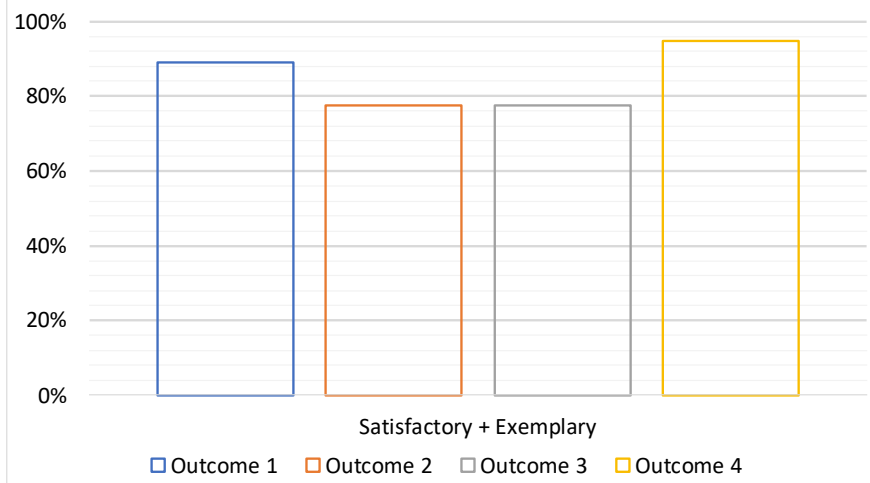

Figure 5. Results for Satisfactory and Exemplary levels combined for each learning outcome

\section{B. Feedback obtained from students after completing their ARP1 course project}

From the 817 students enrolled in the ARP1 course, 707 students took the survey designed by the instructors. From the multiple questions included in the survey, 4 were related to the problem-solving, and thus these are the ones presented in this document. The results for the 4 questions were as follows.

When the students were questioned whether learning Design Thinking in the ARP1 course contributed to their professional development, 52\% respondents completely agreed; while only $3 \%$ respondents either completely or somehow disagreed with the statement (Figure 6).

When the students were questioned about their teamwork abilities, $44 \%$ of freshmen students completely agreed and $37 \%$ partially agreed that they have improved their teamwork performance due to the ARP1 course. Only 5\% respondents underestimated the impact of the course in this particular field (Figure 7).
Has the course contributed to your professional development?

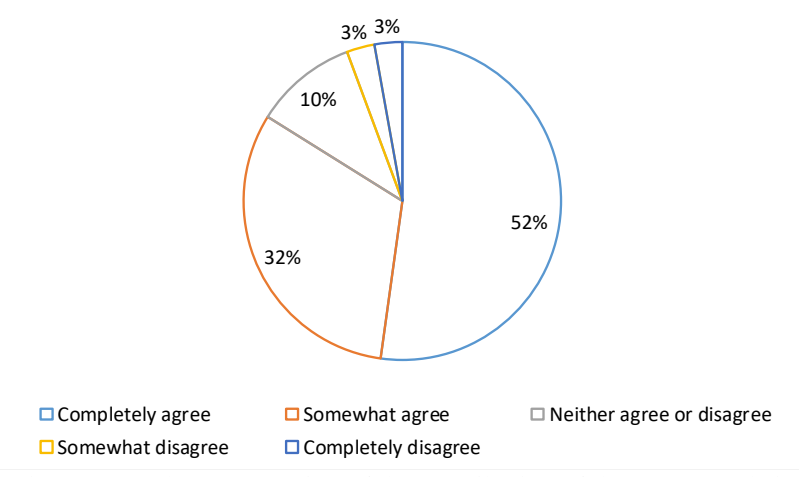

Figure 6. Students perception of the contribution of the course to their professional life.

$$
\text { taking the design thinking course? }
$$

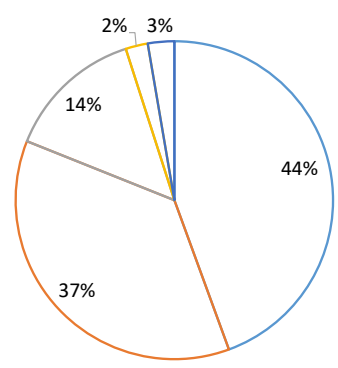

$$
\begin{aligned}
& \square \text { Completely agree } \quad \square \text { Somewhat agree } \quad \square \text { Neither agree or disagree } \\
& \square \text { Somewhat disagree } \square \text { Completely disagree }
\end{aligned}
$$

Figure 7. Students perception of the contribution of the course to develop their team work ability

Most of the students have a positive perspective about their ability to be creative after taking the ARP1 course. From their responses, $42 \%$ respondents completely agreed and 39\% somewhat agree with the statement. Roughly $5 \%$ of the students considered that their creativity has not been improved considerably (Figure 8).

Figure 9 depicts the most relevant question asked for this study. As stated before, the main objective of ARP1 as a core course for all undergraduate programs at ESPOL, is to nurture the ability to solve real-life problems. The vast majority of students $(83 \%)$ consider that their ability to tackle real-life problems has improved due to the ARP1 course, and less than $5 \%$ think the opposite to some degree.

\section{Sponsors feedback regarding the impact of the ARPI} course

ESPOL designed the ARP1 course aiming to confront students with real-life problems. It is important that ESPOL initiative remains active in time; therefore, the perspective of

17 $7^{\text {th }}$ LACCEI International Multi-Conference for Engineering, Education, and Technology: "Industry, Innovation, And Infrastructure for Sustainable Cities and Communities", 24-26 July 2019, Jamaica. 
the sponsors involved in such projects is extremely important to continually increase the academia-society interaction pursued with this initiative.

Has your ability to be creative improved after taking the course?
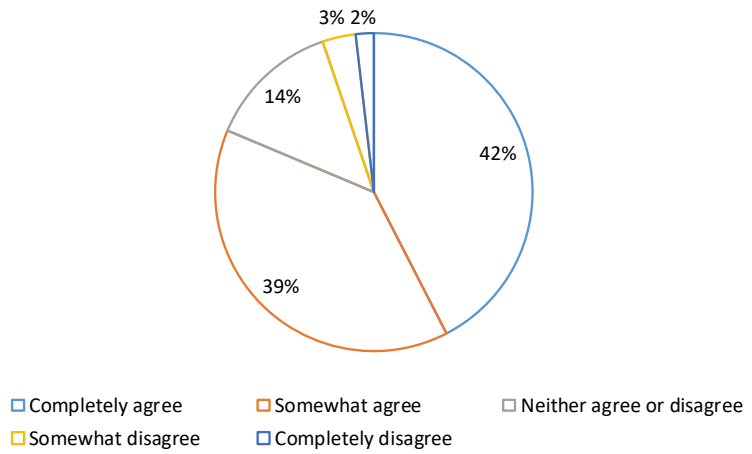

Figure 8. Students perception of the contribution of the course to their creativity

Has your capacity to analyze and solve problems improved after taking the course?

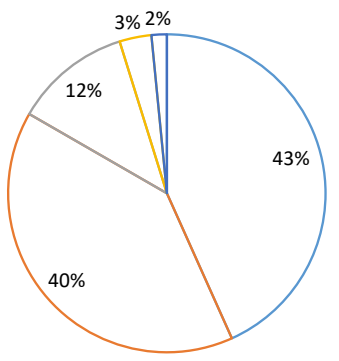

$\square$ Completely agree

$\square$ Somewhat agree

$\square$ Neither agree or disagree

$\square$ Somewhat disagree

Completely disagree

Figure 9. Students perception of the contribution of the course to their problem-solving abilities

A total of 40 sponsors took the 10-question survey designed by the instructors. Five questions are related to the problemsolving topic. The results are as follows.

Most of the problems presented by sponsors needed an innovative solution that, for different reasons, had not been tackled satisfactorily. Part of the problematic responds to an inadequate assessment of the understanding of the problem itself. Hence, it is remarkable that 4 out of 5 sponsors considered that the Design Thinking methodology that is taught in the ARP1 course and applied by freshmen students has contributed to the understanding of the problem at their organizations. Only $10 \%$ respondents completely disagreed with the statement (Figure 10).
Have the methodology and work performed by students contributed to your organization's understanding of the problem?

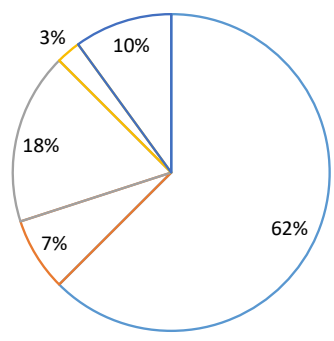

$\square$ Completely agree $\quad \square$ Neither agree or disagree $\square$ Somewhat agree $\square$ Somewhat disagree $\square$ Completely disagree

Figure 10. Sponsors' perception of the course contribution to the understanding of the problem

When sponsors were asked about the efficiency of the solution proposed by the students, half of respondents completely agreed with the student's contribution, 30\% somewhat agreed, $2 \%$ were ambivalent and $18 \%$ were to some degree dissatisfied with the solution proposed (Figure 11).

Have the methodology and work performed by students contributed to solving your organization's problem?

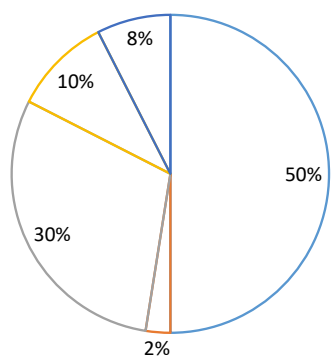

$\square$ Completely agree $\square$ Somewhat disagree

$\square$ Neither agree or disagree $\square$ Somewhat agree

$\square$ Completely disagree

Figure 11. Sponsors' perception of the course contribution to the resolution of the problem

Due to the scope of the course and, in some cases, lack of funding, the solutions students proposed by the end of the course reached only up to the high-fidelity prototyping level. Therefore, the implementation of the solution is up to sponsors to be applied in the future. When asked about their interest in implementing the solution proposed by the students. $48 \%$ respondents completely agreed, while only $10 \%$ of sponsors completely disagreed with the possibility to implement the proposed solution (Figure 13).

$17^{\text {th }}$ LACCEI International Multi-Conference for Engineering, Education, and Technology: "Industry, Innovation, And Infrastructure for Sustainable Cities and Communities", 24-26 July 2019, Jamaica. 
Is your organization interested in implementing the solutions proposed by the students?

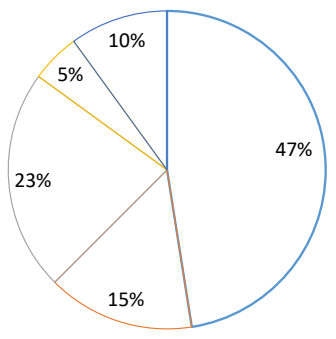

$\square$ Completely agree

$\square$ Somewhat disagree

$\square$ Neither agree or disagree $\square$ Somewhat agree

$\square$ Completely disagree

Figure 12. Sponsors' interest in the implementation of the proposed solution

As it can be seen from Figure 13, sponsors show their willingness to keep collaborating in the future with more ARP1 courses. $62 \%$ of the respondents agreed, in some degree, to repeat the experience with freshmen students using the methodology applied. On the other hand, only $10 \%$ respondents completely disagreed with such statement (Figure 13).

Is your organization interesting in working with new student groups in future semesters to anayze new problems under the same framwork?

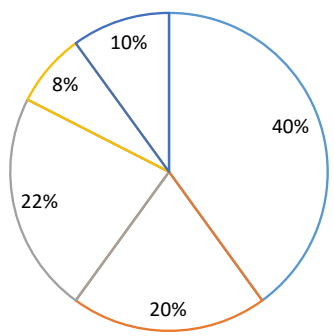

$$
\begin{array}{ll}
\square \text { Completely agree } & \square \text { Neither agree or disagree } \square \text { Somewhat agree } \\
\square \text { Somewhat disagree } & \square \text { Completely disagree }
\end{array}
$$

Figure 13. Sponsors' interest in receiving new students from ESPOL

Due to the sponsor-student interaction during a semester, sponsors were asked about their point of view regarding the importance of the ARP1 course in the professional development of freshmen undergrad students. As it can be seen from Figure $14,68 \%$ respondents completely agreed with the relevance of such an academic interaction in undergraduate programs. On the other hand, only $13 \%$ respondents disagreed, in some degree, with such statement.
Does involving freshmen students in solving real-life problems contribute to their academic and professional development?
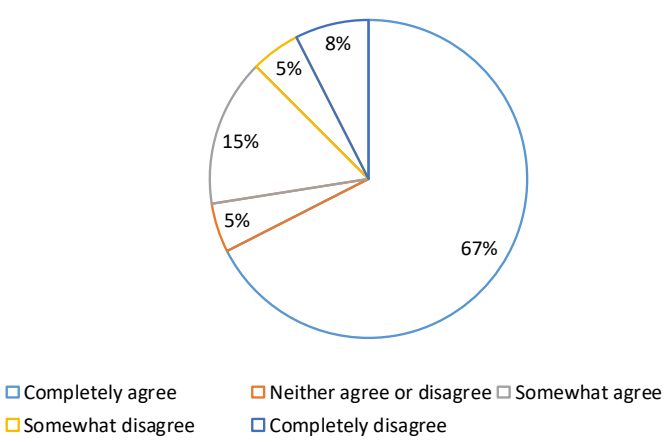

Figure 14. Sponsors' perception of the course contribution to student academic -professional development

\section{DISCUSSION}

\section{A. Evaluation of Learning Outcomes}

Most of students evidence a satisfactory or the highest level of accomplishment for Outcome 1. For the course project, students are required to complete a minimum of interviews to different actors related to the problem assigned. Most groups succeed at correctly identifying the actors directly or indirectly involved with the problem. They also satisfactorily translate the information from interviews and observations into actionable conclusions via empathy tools, such as empathy maps and journey maps. However, when required to research about the problem and obtain information from different sources, students tend to limit this research to contextual information, hence, lacking variety in studies, statistics and trends that could improve their understanding of the problem.

Students are mostly evidencing a satisfactory level of accomplishment for Outcome 2. Although students apply the tools from the methodology in a satisfactory way, most groups evidenced difficulty in identifying insights to later translate into a Point of View (POV). This difficulty may be explained by the fact that research from existing sources was incomplete during the research phase of the methodology. The complexity in identifying insights plays a role as well. The students also found it difficult to match the identified insights, with the user profiles, which consequently affected the quality of their POV statement.

Students are mostly evidencing a satisfactory level of accomplishment for Outcome 3. Although their low and highfidelity prototypes are executed properly, their reports evidence that the validation process was performed with fewer users than expected, affecting the robustness of their conclusions and, hence, attaining an exemplary level. Certain groups had issues when arguing the impact their proposed solutions have on the defined problem; this difficulty may be due to a difficulty in adequately defining the unit of measurement with which they quantified the impact of their solutions.

$17^{\text {th }}$ LACCEI International Multi-Conference for Engineering, Education, and Technology: "Industry, Innovation, And Infrastructure for Sustainable Cities and Communities", 24-26 July 2019, Jamaica. 
As with the previous outcomes, students are mostly evidencing a satisfactory level of accomplishment for Outcome 4. These promising results may be explained by the fact that, throughout the course, students present their progress on their project in five instances, orally. On each of these instances, they receive feedback from instructors and classmates, which help them refine their understanding of the problem and the work done overall.

\section{B. Evaluation of students' survey}

From the students surveyed, it can be inferred that, in general, students perceive that the ARP1 course uses a pertinent methodology. For instance, most of the freshmen students perceived the ARP1 course as a highly valuable mean to enhance their professional performance in the future. This might be due to the empowerment obtained by facing a real-life problem from actual organizations (small and mid-size businesses, associations, NGO's, etc.). Moreover, students must improve their teamwork abilities, as every team is constituted by students from different disciplines, which is acknowledged as a real-life work environment. Additionally, their creativity is activated, given that the Design Thinking methodology requires what is defined as "innovative solutions"; therefore, prototyping and testing different ideas to solve problems were used consistently during the academic semester.

\section{Evaluation of sponsors' survey}

The sponsors perception about ESPOL's approach to develop problem-solving abilities is stated as outstanding. When analyzing the results obtained from the 5 questions surveyed considered in this study, most of the responses fall into the category "Completely agree". This can be explained by the fact that the Design Thinking methodology works towards deeply understanding the problem faced by the sponsors, and demands their participation throughout the process from the very beginning. Additionally, it has been stated that sponsors are willing to receive new freshmen students to analyze other problems at their organizations. Not surprisingly, sponsors affirm the importance of the ARP1 course in the professional development of freshmen undergraduate students, due to the sponsor-student interaction during a semester and the teaching of innovative tools.

\section{CONCLUSIONS AND FUTURE WORK}

The results presented in this study indicate that there is an insightful development of problem-solving skills in the freshmen undergraduate students who took part of the ARP1 course. It is remarkable that these students were facing real-life problems at very early stage in their academic formation, and that the vast majority of sponsors were satisfied with the solutions proposed. It can be inferred that learning outcomes 1, 2 and 3 summarize effectively the DT methodology, while outcome 4 measures the overall ability to communicate the proposed solution.
The results obtained while analyzing the learning outcomes, show satisfactory levels of accomplishment. This may be due to the specificity put into the development of the grading rubrics by the instructors. The pedagogical methodology used by ESPOL to teach Design Thinking in its ARP1 course provides a comprehensive set of tools, both for students and instructors, being the grading rubrics one of the most important ones.

While the most outstanding figures were obtained when analyzing Outcomes 1 and 4, Outcomes 2 and 3 have been the most difficult to attain by students. The students present a lacking understanding of the importance of research from external academic sources. This is understandable, given that more common than not, Ecuadorian high-schools do not strongly emphasize the importance of referencing properly, and considering different sources while performing academic research. Additionally, students struggle to match the identified insights, with the user profiles and consequently POV statement is not correctly stated.

As a whole, the vast majority of students evidence a high performance (Figure 5), suggesting that applying Design Thinking as a framework for the ARP1 course contribute to developing problem-solving skills on students while tackling real-life problems in their community.

One challenge to be tackled in the future is the implementation of the proposed solutions for the problems analyzed. Due to time constraints, and in some cases lack of funding, the proposed solutions reached only the high-fidelity prototype level, but the actual implementation is hardly attained. Under these circumstances, the implementation of the solution is up to sponsors to be done. The fact that sponsors are willing to replicate the DT experience for other problems they face, serve as an indicative that students developed problemsolving abilities and that their solutions have real value for sponsors. Thus, efforts should be carried out in order to motivate implementation and make the sponsor-student interaction sustainable in time.

\section{REFERENCES}

[1] E.Izquierdo, G.Caicedo, G. Chiluiza, "Lessons Learned from an Innovative Approach on an Introductory Entrepreneurship Course: The Case of ESPOL". Proceedings of the International Conference INTEnt, 9-12 July 2006.

[2] H.H. Stevenson, “A Perspective on Entrepreneurship." Harvard Business School Working Paper.1983. \#9-384-131.

[3] S.Venkataraman, The distinctive domain of entrepreneurship research: An editor's perspective. In J. Katz, \& J. Brockhaus (Eds.), Advances in entrepreneurship, firm emergence, and growth. Greenwich, CT: JAI Press.1997.

[4] S.Sarasvathy, Effectuation. Elements of Entrepreneurial Expertise. Cheltenham, UK: Edward Elgar.2008.

[5] S. Guaman-Quintanilla, K. Chiluiza, P. Everaert, and M. Valcke, "Design Thinking in Higher Education: a Scoping Review," in ICERI2018 Proceedings, 2018, vol. 1, pp. 2954-2963.

[6] T. Brown, "Design Thinking,"Harv. Bus. Rev., pp. 84-92, 2008.

$17^{\text {th }}$ LACCEI International Multi-Conference for Engineering, Education, and Technology: "Industry, Innovation, And Infrastructure for Sustainable Cities and Communities", 24-26 July 2019, Jamaica. 
[7] C. Wrigley and K. Straker, "Design Thinking pedagogy: the Educational Design Ladder," Innov. Educ. Teach. Int., vol. 54, no. 4, pp. 374-385, Jul. 2017.

[8] M. Rosa and H. Rozenfeld, " Looking for fundamental elements of design thinking". DESIGN SOC, 2016.

[9] Association of American Colleges \& Universities, "Problem Solving VALUE Rubric.” [Online]. Available: https://www.aacu.org/value/rubrics/problem-solving. [Accessed: 25Feb-2019].

[10] D. H. Jonassen, "Toward a design theory of problem solving," Educ. Technol. Res. Dev., vol. 48, no. 4, pp. 63-85, 2000.

[11] R. M. Gagné, "Learnable aspects of problem solving," Educ. Psychol., vol. 15, no. 2, pp. 84-92, Jan. 1980.

[12] A. Santos , C. González, M. Miño, C. Párraga , M. Calderón, "Design Thinking as a methodology for solving problems: contributions from academia to society".Latin American and Caribbean Journal of Engineering Education,2017 . 